Prace Literackie LVI

Wrocław 2016

DOI: $10.19195 / 0079-4767.56 .3$

JAKUB RAWSKI

Uniwersytet Zielonogórski

\title{
Błędni rycerze Juliusza Słowackiego - Zawisza Czarny i Beniowski
}

\author{
I — nieufny — uśmiechem szyderczym przesłania \\ Możliwość nowych błędów, snów i opętania ${ }^{1}$.
}

Związki Juliusza Słowackiego z Hiszpanią były nad wyraz silne²; poeta uczył się języka hiszpańskiego, żeby móc czytać dzieła Pedra Calderóna de la Barca ${ }^{3}$. W liście do matki z 1831 roku pisał: „Brałem lekcye hiszpańskiego języka i teraz już doskonale rozumiem Donkiszota — nic równego jak Donkihote [...]. Uczyłem się po hiszpańsku jedynie dla Kalderona tragedii, ale dotąd ich nie skosztowałem — co to dla mnie będzie za źródło! jest ich kilkaset"4. Pojawia się tutaj ważny trop, chociaż poeta uczył się języka dla Calderóna, to jednak największe wrażenie zrobił na nim Don Kichot Miguela de Cervantesa Saavedry ${ }^{5}$. Pisze przecież: „nic

${ }^{1}$ B. Leśmian, Don Kichot, [w:] idem, Poezje wybrane, Bielsko-Biała 1995, s. 60.

2 Zob. W. Szturc, Stowacki hiszpański: o sposobie ogladania wydarzeń politycznych, [w:] idem, Archeologia wyobraźni. Studia o Stowackim i Norwidzie, Kraków 2001, s. 29-47.

3 Pedro Calderón de la Barca (1600-1681) — barokowy poeta i dramaturg hiszpański działający w hiszpańskim Złotym Wieku, uważany za następcę Lope de Vegi. Wpływ baroku i Calderóna na twórczość Słowackiego był już wielokrotnie omawiany, począwszy od artykułu Tadeusza Micińskiego, w którym autor twierdził, że przekład Księcia niezłomnego jest „przedziwnym przykładem zewnętrznej zgodności i zasadniczego przetworzenia w duchu”. T. Miciński, Słowacki i Calderon w „,Księciu Niezłomnym”, [w:] idem, Do źródet duszy polskiej, Lwów 1906, s. 65. Zob. również J. Kleiner, Echa calderonowskie w twórczości Stowackiego, „Pamiętnik Literacki” 1914/1915, z. $1 / 4$, s. 205-214.

4 J. Słowacki, Paryż, d. 20 Października, 1831 roku, [w:] idem, Dzieła, red. J. Krzyżanowski, t. XIII. Listy do matki, oprac. Z. Krzyżanowska, Wrocław 1952, s. 31-32.

5 Pierwsza część renesansowej powieści została opublikowana w 1605, natomiast druga w 1615 roku. Pierwsze polskie wydanie w sześciu tomach: Miguel de Cervantes Saavedra, Historya, czyli dzieie i przygody przedziwnego Don Quiszotta z Manszy. Z hiszpanskiego na francuzkie a teraz na polskie przełozone, przeł. F.A. Podoski, Warszawa 1786. Czy Słowacki znał to thumaczenie? Nie wiadomo. Notabene nie musiał, ponieważ uczył się hiszpańskiego, więc mógł czytać w oryginale lub w języku francuskim, którym posługiwał się biegle, ale w cytowanym liście do matki pisze przecież: ,już doskonale rozumiem” Don Kichota. Przysłówek ,już” pozwala domniemywać, iż 
równego jak Donkihote", a nie wspomina na przykład o przetłumaczonym przez siebie (i przy okazji wysoce zreinterpretowanym) ponad dziesięć lat później Księciu niezłomnym ${ }^{6}$.

Będąc we Włoszech, poeta donosił, że posługuje się już językiem hiszpańskim na tyle swobodnie, iż czyta Calderóna w oryginale. W 1837 roku, z Florencji, pisze do rodzicielki: „czasem chodzę rano do biblijoteki czytać po hiszpańsku Kalderona — i upajam się jego brylantową i świętości pełną imaginacją"”. Księcia niezłomnego przetłumaczy w grudniu 1843 roku, utwór wydany zostanie w 1844 roku, w Paryżu ${ }^{8}$, a więc już w czasie kiedy powstaje Zawisza Czarny, a na pewno jest przez Słowackiego obmyślany, dlatego Juliusz Kleiner, zauważając powinowactwo między dwoma tekstami, stwierdza: „rzuceniem najszlachetniejszych pierwiastków duszy własnej garściami na ludzi — miał być także bratni Księciu niezłomnemu dramat, równie jak on z nowych zdobyczy etycznych wysnuty - Zawisza Czarny. Jeszcze jeden poemat ofiary — jeszcze jedne dzieje poświęcenia osobistości dla pełnienia posłannictwa"9. Nie wydaje się jednak, aby z literatury hiszpańskiej wyłącznie Ksiązę niezłomny był pokrewny analizowanemu dramatowi, zasadne jest również zwrócenie uwagi na dzieło Cervantesa.

Na znaczenie Don Kichota dla romantyzmu wskazał jeden z prekursorów epoki - niemiecki filozof Friedrich von Schelling, który uważał dzieło Hiszpana za gatunek powieści nowożytnej zawierający arcyważną mitologię: „Don Kichot i Sancho Pansa są mitologicznymi osobami dla całej kulturalnej ludzkości, podobnie jak opowieść o wiatrakach itp. są prawdziwymi mitami"10. Mitologiczność filozof rozumiał jako symboliczność, zatem dzieje błędnego rycerza, jego przygody, stały się nowoczesnymi symbolami, które inspirowały wyobraźnię romantyków. Sancho uosabia realizm, natomiast don Kichot idealizm, Sancho prozę, don Kichot poezję ${ }^{11}$. Don Kichot posługuje się językiem typowym dla romansów rycerskich, natomiast język Sancho pełni w powieści funkcję języka naturalne-

„dopiero” w pełni pojął utwór Cervantesa, czytając go po hiszpańsku, a nie jak wcześniej (hipotetycznie) w polskim przekładzie dokonanym na podstawie adaptacji francuskiej.

6 Zob. J. Słowacki, Książe niezłomny (z Calderóna de la Barca), oprac. B. Baczyńska, Wroclaw 2009.

7 J. Słowacki, Florencja, d. 3. październ. 1837 r., [w:] idem, Dzieła, red. J. Krzyżanowski, t. XIII, Listy do matki..., s. 329.

${ }^{8}$ Zob. Kalendarz życia i twórczości Juliusza Stowackiego, oprac. E. Sawrymowicz przy współpr. S. Makowskiego i Z. Sudolskiego, Wrocław 1960, s. 755.

9 J. Kleiner, Juliusz Słowacki. Dzieje twórczości, t. 4. Poeta mistyk, oprac. J. Starnawski, Kraków 1999, s. 165.

10 F. Schelling, Filozofia sztuki, przeł. K. Krzemieniowa, Warszawa 1983, s. 390.

11 Tę dychotomię, a tym samym i zadania poezji, na gruncie literatury polskiej zaneguje dopiero Stanisław Grochowiak w wierszu Don Kiszot z debiutanckiego tomu Ballada rycerska (1956) słowami podmiotu lirycznego będącego porte-parole autora: „I nawet w sklepie obwiną ci śledzie/ W moje liryki - wnuka Sanczo Pansy". S. Grochowiak, Don Kiszot, [w:] idem, Poezje wybrane, Warszawa 2001 s. 24. 
go, przeciwstawionego sztucznemu i fałszywemu językowi tychże romansów ${ }^{12}$. Określenie błędny rycerz jest związkiem frazeologicznym, jak również toposem wpisanym w kulturę ${ }^{13}$. „Błędny” po staropolsku oznaczał „błądzący”"14.

Nie brakuje reminiscencji lektury Don Kichota w twórczości Adama Mickiewicza $^{15}$. Cyprian Kamil Norwid uczył się czytać na polskim przekładzie Don Kichota, w październiku 1871 roku pisał w liście do Jadwigi Łuszczewskiej: ,„pierwszą książką, jaką w życiu moim czytałem, był Cerwantesa bohater"16. W wierszu Epos-nasza (1851) uczynił błędnego rycerza przewodnikiem wędrowca, który przemierza świat, marząc o swej prawdzie - uwięzionej Dulcynei. Utwór traktowano jako przykład romantycznej recepcji Don Kichota oraz poetycką autobiografię poety $^{17}$. W utworze Norwida podmiot liryczny zwraca się do bohatera powieści Cervantesa:

Ty jeden wielki znasz to, Don Kichocie,

Jednego ciebie to wspomnienie wzruszy.

Bo gawiedź śmiać się będzie wielolica,

Niewarta ostróg z la Manczy szlachcica! ${ }^{18}$

Punkt wspólny dla Norwida i Słowackiego stanowi przekonanie, że ,bohater Cervantesa jest nie tylko postacią epopeiczną, jest także — w jakiejś przynajmniej mierze - odpowiednikiem romantycznego poety" ${ }^{19}$, a skoro przyjąć takie twierdzenie, to za błędnym rycerzem Zawiszą kryje się nie kto inny, jak romantyczny poeta, czyli Słowacki.

12 Zob. Z. Szmydtowa, Cervantes, Warszawa 1975, s. 175.

13 Topos rozumiem jako złożony obraz o bogatych konotacjach w literaturze, pełniący rozmaite funkcje, ulegający przemianom. Zob. J.M. Rymkiewicz, Myśli różne o ogrodach, Warszawa 2010, s. 17-22.

14 Zob. W. Kopaliński, Stownik wyrazów obcych i zwrotów obcojęzycznych z almanachem, Warszawa 1994, s. 658.

15 Zob. Z. Matkowski, Cervantes w Polsce. I. „Don Kichot” a „Dziady wileńsko-kowieńskie”, „Pamiętnik Literacki” 1918, z. 1/2, s. 26-66; S. Windakiewicz, Prolegomena do „Pana Tadeusza”, Kraków 1918, s. 210-212; K. Wojciechowski, Hrabia w „Panu Tadeuszu” a „Don Kiszot”, Stryj 1900.

16 C.K. Norwid, Pisma wszystkie, t. 9. Listy 1862-1872, oprac. J.W. Gomulicki, Warszawa 1971, s. 497.

17 D. Siwicka, Romantyzm 1822-1863, Warszawa 1999, s. 223. Również zob. T. Korpysz, Nie tylko ,Epos-nasza”. O obrazie Don Kichota w pismach Norwida, [w:] Norwid. Z warsztatów norwidologów bielańskich, red. T. Korpysz, B. Kuczera-Chachulskia Warszawa 2011, s. 9-33; W. Szturc, Norwidowy Don Kichot na tle literatury XIX wieku. O „Epos-nasza” (1848): o sposobie ogladania samotności, [w:] idem, Archeologia ..., s. 148-168. Notabene motto z tego utworu Norwida zaczerpnie Krzysztof Kamil Baczyński do swojego wczesnego wiersza Don Kichot, zob. K.K. Baczyński, Don Kichot, [w:] idem, Utwory zebrane, t. 1, oprac. A. Kmita-Piorunowa, K. Wyka, Kraków 1979, s. 397.

18 C. Norwid, Epos-nasza, [w:] idem, Wybór poezyj, oprac. S. Cywiński, BN I 64, Kraków 1924, s. 26.

19 M. Głowiński, Style odbioru. Szkice o komunikacji literackiej, Kraków 1977, s. 118. 
W piśmiennictwie polonistycznym przyjęło się zaliczać Zawiszę Czarnego do okresu mistycznego w twórczości wieszcza. Nie ma wobec tego zaklasyfikowania wątpliwości. Słowacki rozpoczął pracę nad dramatem najprawdopodobniej w 1844 roku, a więc już po opublikowaniu Beniowskiego (1841), poematu, który wniósł nową jakość do literatury romantycznej, ponieważ dokonała się w nim „wielka destrukcja języka romantycznej poezji” ${ }^{20}$, nastąpił „kryzys indywidualizmu romantycznego" 21 , a poeta z dystansem potraktował kwestie bogoojczyźniane. Zastosowany przez Słowackiego kod wpisuje się w dyskurs ironii romantycznej, która „nie buduje wyraźnej wspólnoty śmiechu, ale jest raczej formą niejawnego porozumienia wykluczającego tych, którzy nie odkryją ukrytego przekazu. Śmiech rodzi się tu ze zbudowania dystansu między tekstem a podmiotem, który mimo to skazany jest na językową ekspresję. Ta sprzeczność rodzi autoironiczny śmiech"22. W pieśni trzeciej został wyśmiany romantyczny model wieszcza, postawionego obok szafy i żyrafy, ironicznymi słowami podmiotu lirycznego będącego porte-parole autora:

Z płaczem mówiła: jak w dębową szafę

Wlazła przed wrogów okrutnych pogonią,

Jakie tam miało być z niej auto-da-fe,

Jak nie pamiętał nikt i nie dbał o nią. -

(O! hor[r]or! trzeci rym jest na żyrafę!

Muzy żałosne łzy nade mną ronią,

Bo muzy wiedzą, jakie do łez prawo

Ma wieszcz piszący poemat oktawą) $)^{23}$.

Od tego momentu, czyli od roku 1841 (to jest również roku niedoszłego pojedynku ze Stanisławem Ropelewskim, o czym poniżej), literatura tworzona przez Słowackiego nie będzie już taka sama jak dawniej, ponieważ poeta zacznie posługiwać się innym, nowym językiem ${ }^{24}$. Czy musi to jednak oznaczać, że dramaturg porzucił ironię, groteskę, niechęć wobec przesadnie manifestowanych akcentów narodowowyzwoleńczych? Przeciwnie. Zawisza Czarny nie jest (albo nie jest wyłącznie) manifestacją filozofii genezyjskiej, uwznioślonego mistycyzmu, „narodową tragedią ofiary” "25, „tragedią mistyczną"26. Nie można zatem przyjąć twierdzenia, że „Słowacki utwierdzał się [...] w przekonaniu, iż ofiara

20 J.M. Rymkiewicz, Juliusz Stowacki pyta o godzinę, Warszawa 2014, s. 36.

21 Zob. S. Treugutt, ,,Beniowski”. Kryzys indywidualizmu romantycznego, Warszawa 1999.

22 M. Michalski, Komizm jako rewizjonistyczna kategoria historycznoliteracka, „Słupskie Prace Filologiczne. Seria Filologia Polska” 2007, nr 5, s. 201.

23 J. Słowacki, Beniowski. Poema, [w:] idem, Dzieła wybrane, red. J. Krzyżanowski, t. 2. Poematy, oprac. J. Krzyżanowski, Wrocław 1983, s. 133. O znaczeniu tego fragmentu Beniowskiego dla recepcji utworu i jego znaczenia w twórczości Słowackiego pisze również Jarosław Marek Rymkiewicz, zob. idem, Juliusz Stowacki pyta o godzinę..., s. 32.

24 Zob. J.M. Rymkiewicz, Juliusz Stowacki pyta o godzinę..., s. 36-37

25 B. Lasocka, Gatunki dramatyczne w twórczości Stowackiego i ich modyfikacje, [w:] Stowacki teatralny, red. K. Kurek, Poznań 2006, s. 80.

${ }^{26}$ Ibidem, s. 81. 
pozostaje w dziejach Polski najwyższą wartością, i dał temu wyraz w kolejnym dziele dramatycznym" 27 . Wydaje się, że jedna z podstawowych funkcji utworu to ukazanie gorzkiego, miejscami groteskowego, obrazu polskich mitów narodowych poprzez celową reinterpretację tytułowego bohatera - będącego symbolem tychże mitów, a co za tym idzie również wad narodowych — jako błędnego rycerza. Wskazanie analogii oraz związków z Don Kichotem pozwala uzasadnić przedstawione twierdzenie. Warto przypomnieć, że reminiscencje słynnego dzieła Cervantesa w twórczości Słowackiego omówiła Zofia Szmydtowa na przykładzie takich utworów, jak Podróż do Ziemi Świętej z Neapolu ${ }^{28}$, Beniowski (poemat) ${ }^{29}$, Fantazy $^{30}$ oraz Lila Weneda ${ }^{31}$. Do tej pory nikt jednak nie wskazał, poza paroma sugestiami (o czym poniżej), wyraźnych związków i analogii Don Kichota z Zawisza Czarnym.

Intertekstualność, na potrzeby niniejszych rozważań, jest rozumiana jako miejsce, w którym dochodzi do spotkania dwóch lub więcej tekstów, gdy utwory wchodzą z sobą w dialog. To zjawisko wielokrotnie już rozwijane oraz opisywane w naukach humanistycznych zawdzięcza swój początek badaniom Julii Kristevej, która stwierdziła, że „każdy tekst jest zbudowany z mozaiki cytatów, jest wchłonięciem i przekształceniem innego tekstu”32. Francuska uczona „porównuje intertekst do drzewa, do czegoś pomiędzy jednością a wielością. Mnogi, lecz nie bezforemny korzeń, pień, gałęzie i liście to sieć powiązań, odwołań, aluzji, przetworzeń i odniesień międzytekstowych" ${ }^{33}$. W takim rozumieniu Zawisza Czarny Słowackiego zostaje potraktowany jako tekstualny obszar powiązań, w którym główny punkt odniesienia stanowi słynna powieść Cervantesa wraz z całym korpusem motywów i zjawisk pojawiających się w niej.

Dla pierwszego monografisty Słowackiego — Antoniego Małeckiego — Zawisza z omawianego dramatu to „osobistość tajemnicza, głęboka, nieodgadniona, słowem mesyaniczna"34. Prawie sto lat później Franciszek Ziejka nazywa tego samego bohatera błędnym rycerzem: „Słowacki zdecydował się bowiem stworzyć

27 Ibidem, s. 80.

28 Zob. Z. Szmydtowa, Stowacki - Cervantes. Zwiąki i analogie, [w:] eadem, Poeci i poetyka, Warszawa 1964, s. 230-232. Na temat fragmentu Podróży do Ziemi Świętej z Neapolu w kontekście Don Kichota również zob. W. Szturc, Stowacki hiszpański..., s. 34-35.

29 Zob. Z. Szmydtowa, Stowacki - Cervantes..., s. 232-235. Na temat Beniowskiego (poematu) w kontekście Don Kichota również zob. G. Leszczyński, ,, Mise en abyme”. (Anty)narcystyczne piękno „Beniowskiego”, [w:] Piękno Juliusza Słowackiego, t. III. Metamorphosis, red. J. Ławski, A. Janicka, Ł. Zabielski, Białystok 2015, s. 303, 307, 310.

30 Zob. Z. Szmydtowa, Stowacki - Cervantes..., s. 233.

31 Zob. ibidem, s. 238-245, 253-254.

32 J. Kristeva, Stowo, dialog i powieść, przeł. W. Grajewski, [w:] Bachtin. Dialog - JęzykLiteratura, red. E. Czaplejewicz, E. Kasperski, Warszawa 1983, s. 396.

33 T. Kitliński, Podmiot w procesie wedlug Julii Kristevej, [w:] Podmiot w procesie, red. J. Jusiak, J. Mizińska, Lublin 1999, s. 50.

34 A. Małecki, Juliusz Stowacki. Jego życie i dzieła w stosunku do współczesnej epoki, t. 3 , Lwów 1881, s. 111. 
na kanwie losów Sulimczyka wielką dramatyczną opowieść... o błędnym rycerzu z Garbowa, który nieoczekiwanie staje się uosobieniem esencji ducha polskiego, losu polskiego"35. Kleiner nazwie bohatera Słowackiego dalekim krewniakiem don Kichota ${ }^{36}$. „Błędnym rycerzem” Zawiszę określi Julian Krzyżanowski ${ }^{37}$. Andrzej Kotliński najpełniej, jak do tej pory w piśmiennictwie polonistycznym, określił zależności między Zawiszą a jego hiszpańskim antenatem:

Don Kichot — szlachetny, samotny, szalony i nieszczęśliwy — to niezwykle ważny analogon „pana Czarnego”. Zawisza, jak nieśmiertelny bohater Cervantesa — jest i wzniosły, i godzien litości. Jak tamten uosabia poezję i jak on nie pasuje do rzeczywistości. Cierpienia Zawiszy, który jak Don Kichot żyje na granicy realnego i nierealnego, są przecież wzbogacone pierwiastkiem o jeszcze innym ciężarze gatunkowym. Wędrującemu bohaterowi Słowackiego ustawicznie towarzyszy — bolesne i mącące myśli — przeczucie nadciągającej niechybnie, choć jeszcze odległej klęski ojczyzny $^{38}$.

W formie komentarza do zacytowanych słów Kotlińskiego warto przypomnieć, że Cervantes napisał Don Kichota jako parodię eposów rycerskich, jego celem było „obalenie autorytetu i ukrócenie popularności, jaką w świecie i pośród pospólstwa cieszą się księgi rycerskie"39. Powieść jest aktem negacji, sprzeciwu wobec utrwalonych w eposach i poematach wzorców kulturowych. Ryszard Nycz przypomina, że ,pojawienie się parodii określonych wzorców jest [...] uznawane za symptom ich kryzysowego stadium, jak też »ukryty«, nie bezpośredni, sposób walki z zastanymi konwencjami, przyspieszający proces zmiany stylów literackich i »oczyszczający pole« dla przyjęcia innowacji formalno-technicznych"40. Podstawową funkcję Don Kichota stanowi kpina, celowe zniekształcenie rzeczywistości, a więc ujęcie groteskowe. Utwór obrazuje także kryzys męskości rycerskiej $^{41}$; zwiastuje nie tylko przemiany społeczne, lecz także przemiany mentalne. Hiszpańskiego błędnego rycerza należy traktować ,jako bardzo sugestywny wizerunek bohatera, a ściślej mówiąc - antybohatera oszukanego, to znaczy uwiedzionego przez Ideologiczną Triadę w jej wariancie rycerskim. Groteska nie oszczędziła żadnego z jej elementów: wojny, bohaterstwa i męskości”42. Jeżeli przyjąć, że Zawisza stanowi kolejne wcielenie błędnego don Kichota, trzeba uznać również jego szaleństwo, groteskowość i męską rycerskość w kryzysie, nie tylko cierpienie, tragizm, mistycyzm czy uporczywe myśli o nadchodzącej klęsce

35 F. Ziejka, „Polegaj jak na Zawiszy”, „Pamiętnik Literacki” 1984, z. 1, s. 164.

36 Zob. J. Kleiner, Juliusz Słowacki. Dzieje twórczości, t. 4. Poeta mistyk..., s. 179.

37 Zob. J. Krzyżanowski, Twórca nowoczesnego dramatu polskiego, [w:] idem, W świecie romantycznym, Kraków 1961, s. 190.

38 Zob. A. Kotliński, Mistrz „,czerwonego rymu”. Stowacki, Warszawa 2000, s. 82.

39 M. de Cervantes Saavedra, Prolog, [w:] idem, Przemyślny szlachcic don Kichot z Manczy, przeł. i oprac. W. Charchalis, Poznań 2014, s. 78.

40 R. Nycz, Tekstowy świat. Poststrukturalizm a wiedza o literaturze, Kraków 2000, s. 220.

41 Zob. T. Tomasik, Od Don Kichota do Robinsona Cruzoe — kryzys męskości rycerskiej, [w:] idem, Wojna - męskość - literatura, Słupsk 2013, s. 67.

42 Ibidem. 
ojczyzny. Przywołane powyżej stanowiska badawcze zakreślające analogie pomiędzy Zawiszą z utworu Słowackiego i bohaterem powieści Cervantesa nie są bezpodstawne. Przeciwnie, lektura dramatu przynosi potwierdzenia zaprezentowanych tez. Ironia oraz groteska są jednymi z podstawowych komponentów estetycznych Don Kichota oraz Zawiszy Czarnego; analogie są dostrzegalne również w kreacji i zachowaniach bohaterów.

Dzieje najsłynniejszego błędnego rycerza w powieści Cervantesa rozpoczynają się w momencie, gdy naczytawszy się rycerskich eposów ${ }^{43}$, „kompletnie dobił swój rozum [...] uznał za słuszne i konieczne, zarówno dla większej chwały swego honoru, jak również dla służby swemu narodowi, stać się błędnym rycerzem i wyruszyć w świat konno z bronią w ręku na poszukiwanie przygód" ${ }^{4}$, więc ,porzuciwszy leniwe piernaty, dosiadł słynnego rumaka swego Chabettona i przed się ruszył poprzez pradawne i sławetne równiny Montielu. I rzeczywiście jechał po tych równinach" ${ }^{25}$. Od tego momentu jego życie będzie opierało się na podróży, ciągłym przemieszczaniu się w poszukiwaniu rycerskich przygód. Analogię odnaleźć można w dramacie Słowackiego. Zawisza po zwycięskiej bitwie grunwaldzkiej mówi do Dziada o nieustannej wędrówce, zgodnie z rycerską powinnością: „Pod Grunwaldem onegdaj — w Czechach wczoraj — jutro na granicy Węgier przeciw Turkom będzie Zawisza... Powiadam ci - [...] w tej ciągłej wandrówce"46. Co ważne, don Kichot wyrusza w świat jako człowiek szalony z powodu nadmiernej ilości lektur. W stanie szaleństwa, chociaż inaczej warunkowanego, wędruje Zawisza. Ostatecznie opuści nawet ukochaną Laurę dla podróży, która zakończy się jego śmiercią podczas wyprawy cesarza Zygmunta Luksemburskiego na Turków:

Tak więc, Panno... oto ja wyjadę

Sam z moim Głupcem tylko - i Mandułą,

Którzy mi staną za ludzi gromadę

(ZC, red. D, akt I, s. 480).

43 Czytanie prowadzące do całkowitego zatracenia w świecie fantazmatów literackich i próby egzystowania według wzorców zaczerpniętych z literatury, które kończy się klęską przez zderzenie iluzji z rzeczywistością, podobnie jak w Don Kichocie, jest jednym z głównych wątków postromantycznej Pani Bovary (1857). Zob. G. Flaubert, Pani Bovary. Z obyczajów prowincji, przeł. R. Engelking, Gdańsk 2005.

44 M. de Cervantes Saavedra, Przemyślny szlachcic don Kichot z Manczy, przeł. i oprac. W. Charchalis, s. 103. W najnowszym, cytowanym w niniejszej dysertacji, thumaczeniu pierwszego tomu przygód don Kichota autorstwa Wojciecha Charchalisa, będącym zarazem pierwszym wydaniem krytycznym powieści Cervantesa, Rosynant zwie się Chabettonem, Dulcynea Cudenią, a Sanczo Pansa Sanczo Brzuchaczem.

45 Ibidem, s. 109.

46 J. Słowacki, Zawisza Czarny, Ustępy zaniechane, red. B, oprac. J. Kleiner, W. Floryan przy współpr. J. Pelca, [w:] idem, Dzieła wszystkie, red. J. Kleiner, przy współpr. W. Floryana, t. XII, cz. 2, Wrocław 1961, s. 376. Dalsza paginacja cytatów z tego wydania utworu, oznaczonego skrótem ZC oraz odwołań do niego jest zlokalizowana w tekście głównym, w nawiasach. Objaśnienia innych skrótów: red. — redakcja. 
Don Kichot przemierza świat w towarzystwie wiernego i oddanego Sancho, który „zostawił żonę i dzieci i zobowiązał się służyć sąsiadowi w charakterze giermka"47. Zawisza ma giermka Mandułę (który jest tak naprawdę kobietą Zorianą — w męskim przebraniu ${ }^{48}$ ) bezgranicznie wiernego swemu panu, o czym sam mówi:

I od dawna już tego rycerza prowadzę

$\mathrm{Z}$ miesięcznymi duchami, a sam idę przodem

Jak pies wierny... przed ślepym rycerzem — rapsodem...

(ZC, kontynuacja C2, s. 406).

Manduła niewątpliwie dorównuje Sancho w wierności, jednak obie postawy są podyktowane innymi zależnościami. Sancho Brzuchacza przypomina, o wiele bardziej niż Manduła, drugi giermek Zawiszy — Głupiec. Na tę zależność zwrócił uwagę Kleiner, stwierdzając, że Głupiec to „odległy potomek Sancho Pansy"49. Sancho jest człowiekiem łatwowiernym i lekkomyślnym, o czym najlepiej świadczy chęć towarzyszenia don Kichotowi oraz przekonanie, które wyraził w następujących słowach: „mam tak znakomitego pana, który będzie potrafił dać mi wszystko, co będzie dla mnie dobre, a ja będę mógł to unieść" ${ }^{50}$. W dramacie Słowackiego Głupiec (nomen omen), ma te same cechy co Sancho: jest poczciwym, lekkomyślnym towarzyszem podróży, który służy Zawiszy z iście psim oddaniem. Rycerz charakteryzuje go następująco:

Lecz głupiec kiedy się uda,

To lepszy od jurysty lub kupca,

Bo się sam psom czterem nie da

I pana swego nie przeda...

Bo wierniejszy od sobaki...

Otóż mój głupiec — taki...

(ZC, red. D, akt I, s. 433-434).

Głupiec mówi do swego pana, oczywiście prozą: „I znów my, Panie Czarny, w polu, jak wróble i kruki - a gdzie my jedziemy, to ja nie wiem; bo jeśli bić się za ojczyznę... to koń mój do ojczyzny ledwo przyczepiony ogonem...." (ZC, red. D, akt II, s. 489). Na te słowa Zawisza odpowiada $z$ iście donkiszotowskim uporem, zacięciem i przekonaniem, krytykując brak bitewnego zapału Głupca: „Milcz, durniu - nie tobie to rezonować o mapie narodów... Czy ty wiesz, że gdzie kończy się Polska, tam się piekło zaczyna... a gdzie jam jest, tam bramy piekielne nie przemogą?... Skryj konie za kurhanem, aby nas jakie hultajstwo nie spostrzegło czerniących się pod zorzą... i nie opadło hurmem... bom smut-

47 M. de Cervantes Saavedra, Przemyślny szlachcic..., s. 149.

48 Tożsamość Manduły odgaduje Trynitarz, zob. ZC, red. B, fragment I, s. 371.

49 J. Kleiner, Juliusz Stowacki. Dzieje twórczości, t. 4. Poeta mistyk..., s. 179.

50 M. de Cervantes Saavedra, Przemyślny szlachcic..., s. 151. 
ny i chciałbym się na kwiecinach polskich wyspać na trzy noce..." (ZC, red. D, akt II, s. 490). Dialogi między Zawiszą i Głupcem przypominają te, które toczył don Kichot i Sancho.

Zawisza przekonuje samego siebie o własnym męstwie: „bom człowiek... i mąż... a nie żaden mazgaj trefiony" (ZC, red. B, fragment II, s. 375), czyni podobnie w tym względzie jak don Kichot, który również nieustannie, werbalnie, udowadnia swoje męstwo: ,jam jest waleczny don Kichot z Manczy, mściciel krzywd i niesprawiedliwości" ${ }^{1}$. Hiszpański bohater ma jednak świadomość, że „,człowiek nie jest wart więcej niż inni, jeśli nie czyni więcej niż inni" 52 , dlatego czyn, chęć dokonania wielkiego czynu staje się sensem i jądrem egzystencji Zawiszy:

Myśl moja w dzień pracuje — we śnie nie spoczywa,

Jest coś strasznego - co mię do walki wyzywa!..."

(ZC, kontynuacja C2, scena III, s. 405).

Don Kichota i Zawiszę łączy podobieństwo fizyczne. Rycerz Słowackiego to mężczyzna szczupły i schorowany, przedstawiony zupełnie odmiennie niż w obrazie Jana Matejki Bitwa pod Grunwaldem:

\footnotetext{
I przez wszystkie żeber szpary

Przewiała nędza.... okrutna....

Serce... jak liść suchy gore.....

Twarz... obacz... chuda i smutna...

(ZC, kontynuacja C2, scena III, s. 405).
}

Dostrzegalna jest analogia z don Kichotem, który ,był krzepkiej postury o wysuszonym ciele, pociągłej twarzy"53.

Opierając się na wydaniu Kleinera, w ostatniej scenie aktu III, redakcji D, będącej zarazem zakończeniem dramatu (nie wliczając ustępów zaniechanych i rzutów pierwotnych), Zawisza przeczuwa nadchodzącą śmierć w trakcie wyprawy przeciw Turkom, mówi:

Nie z żadną dumą i pychą,

Spokojnie przejadę - cicho,

W czarne me zakuty miedzie,

Jak człowiek, co na śmierć jedzie,

Na szwank stawia garstkę kości,

A nie dba, czy mu kto zazdrości,

(ZC, red. D, akt III, fragment II, s. 496).

Śmierć, chociaż chwalebna, na polu chwały nie przyniesie zwycięstwa, to już podpowiada historia, nie literatura. Słowacki nie zdecydował się (nie zdążył? nie chciał?) dopowiedzieć losów Zawiszy. Związek z Don Kichotem, który zarysowuje się w zacytowanych słowach, uchwyciła Z. Szmydtowa, ogólnie komentując relację pisarstwa Słowackiego z dziełem Cervantesa:

51 Ibidem, s. 125.

52 Ibidem, s. 250.

53 Ibidem, s. 100. 
Temat chwalebnej klęski nabrał szczególnej wagi dla poety polskiego po upadku powstania. Krytycznie usposobiony do emigracji, nie chciał jej łudzić zwycięstwem. Nie mająca za sobą mas, oderwana od kraju, jakże się mogła spodziewać wygranej? Słowacki szedł jeszcze dalej, uznając całe swe pokolenie za niezdolne do czynu, skazane na „bezskuteczne usiłowania”. Cóż mieli począć najlepsi z tego pokolenia, jeśli nie szukać rozwiązania dla swej tragicznej egzystencji poza sferą zwycięstwa. W znalezieniu sensu dla wysiłków podejmowanych na próżno, dla nie dających się uniknąć klęsk i zawodów mógł dopomóc Słowackiemu Cervantes jako autor Don Kiszota ${ }^{54}$.

Czy Zawisza jest jedynym błędnym rycerzem w twórczości Słowackiego? Z pewnością nie. Tego toposu należy szukać także we wczesnym pisarstwie wieszcza. W liście dedykacyjnym do Zygmunta Krasińskiego, który należy traktować jako przedmowę do Balladyny z 1834 roku, poeta pisał: „Bo ileż to razy patrząc na stary zamek, koronujący ruinami górę mego rodzinnego miasteczka, marzyłem, że kiedyś w ten wieniec wyszczerbionych murów nasypię widm, duchów, rycerzy [J.R.]"55. To pragnienie Słowacki spełnia, wprowadzając do dramatu postać Kirkora - błędnego rycerza. Nie może zostać określony mianem „szalonego”, ale z pewnością egzystuje w świecie wyidealizowanym, naiwnym; podobnie jak don Kichot. Kirkor poszukiwał kobiety czystej, bez skazy, kandydatki na żonę idealną, którą pokocha miłością rycerską:

Białą, jak w ręku anielskiego stróża

Kwiat lilijowy — niech jej słowik śpiewny

Zazdrości głosu, a synogarlica

Wiernością zrówna... gdzie taka dziewica ${ }^{56}$.

Podobnie don Kichot, gdy osiodłał konia i przywdział zbroję: „zrozumiał, że trzeba mu już tylko poszukać damy, w której by się zakochał — bo błędny rycerz bez miłości jest jak drzewo bez liści" ${ }^{57}$, więc spotkał Cudenię (Dulcynę), której „uroda jest nadludzka, przecież w niej urzeczywistniają się wszystkie niemożliwe i fantastyczne atrybuty, które poeci przypisują swoim damom: jej włosy to złoto, jej czoło pola elizejskie, brwi to niebiańskie łuki, jej oczy są słońcami" ${ }^{58}$ itd. Kirkor do tego stopnia zatracił kontakt z rzeczywistością, że nie tylko nie domyślił się, jakiego czynu dokonała Balladyna, aby zostać jego żoną, ale również nie dostrzegł, z jakimi zamiarami pojawiła się na jego dworze, nie zastanawiał się nad jej prawdziwymi intencjami dotyczącymi zdobycia korony, przejęcia władzy. Przed swoim wyjazdem powiedział do niej:

W skarbcu masz pieniążki,

Szafuj... i baw się... — daj mi czoło białe ${ }^{59}$.

54 Z. Szmydtowa, Stowacki - Cervantes..., s. 254-255.

55 J. Słowacki, Kochany poeto ruin!, [w:] idem, Balladyna, oprac. M. Inglot, BN I 51, Wrocław 1976, s. 4-5.

56 Ibidem, s. 11.

57 M. de Cervantes Saavedra, Przemyślny szlachcic..., s. 105.

58 Ibidem, s. 196-197.

59 J. Słowacki, Balladyna..., s. 109. 
Wyjazd Kirkora i jego słowa doprowadzą, jak wiadomo, do smutnego finału. Względem powyższego stanowiska badawczego, błędnego rycerza z Balladyny można zaliczyć do tzw. bohaterów toksycznych i ich podkategorii „bezbarwnych mięczaków" wedle rozpoznania Małgorzaty Frankiewicz korzystającej z psychologicznej typologii Lilian Glass ${ }^{60}$.

Wpływ don Kichota, jako bohatera literackiego, na Słowackiego nie ogranicza się wyłącznie do intertekstualnej relacji w literaturze. Pojawił się w życiu poety dzień, który sam nazwał, nie bez powodu, „donkiszotowskim”. Chodzi o słynny, niedoszły pojedynek z Ropelewskim, który miał się odbyć w czerwcu 1841 roku. Słowacki wówczas, 16 czerwca 1841 roku, rozpoczyna list do Joanny Bobrowej od następujących słów: „Przebyłem nareszcie mój dzień Donkiszotowski, nogę silnie postawiłem na szali i podniosłem w górę całą zgraję jezuitów, potem zdjąłem ją i poupadali w błoto, ale w błoto, z którego się już nie wygrzebią tak prędko — niech spoczywają" ${ }^{1}$, dalej dodaje: „Litwini postanowili mnie zabić lub upokorzyć" $" 62$. List ten stanowi notabene swoisty, literacki protokół z nieodbytego pojedynku, który, gdyby został zrealizowany, mógłby skutecznie zaważyć na historii literatury, wtedy bowiem „dzieje romantyzmu polskiego [...] kończyłyby się ostatecznie i bezapelacyjnie 15 czerwca 1841 roku"63. Wbrew kategorycznym stwierdzeniom utrwalonym w piśmiennictwie polonistycznym rozgrywka nie doszła do skutku nie ze względu na „tchórzostwo" Ropelewskiego ${ }^{64}$, lecz akt darowania Słowackiemu życia przez krytyka ${ }^{65}$.

Najważniejsze jednak dla niniejszych rozważań jest przypomnienie tezy, że poeta zachował się tak samo jak rycerz z Manczy, ,,wystąpił po rycersku do walki, tylko że nie miał się z kim bić. Przeciwnik nie przybył na miejsce spotkania. Doszło, jak w większości przygód Don Kiszota, do manifestacji odwagi bez jakichkolwiek skutków praktycznych"66. Notabene w opublikowanym w tym samym roku Beniowskim, w którym zaatakował całą emigrację, nie szczędząc jej szyderstw (co stało się przecież bezpośrednim powodem wyzwania na pojedynek), w pieśni drugiej podmiot liryczny, będący porte-parole Słowackiego, utożsamił siebie $\mathrm{z}$ don Kichotem:

${ }^{60}$ Zob. M. Frankiewicz, Toksyczni bohaterowie dramatów Stowackiego (czyli poeta w szponach postmodernizmu), [w:] Juliusz Słowacki - poeta europejski, red. M. Cieśla-Korytowska, W. Szturc, A. Ziołowicz, Kraków 2000, s. 189.

61 J. Słowacki, Dzieła, red. J. Krzyżanowski, t. XIV. Listy do krewnych, przyjaciół i znajomych (1820-1849), oprac. J. Pelc, Wrocław 1959, s. 147.

62 Ibidem.

63 J.M. Rymkiewicz, Juliusz Stowacki pyta o godzinę..., s. 26.

64 Zob. P. Hertz, Portret Stowackiego, Warszawa 2009, s. 131.

65 Zob. L. Libera, Stanisław Ropelewski - krytyk romantyczny, [w:] idem, Mickiewicz i medycyna. Szkice romantyczne, Zielona Góra 2010, s. 39-63; J. Lyszczyna, Stanisław Ropelewski — krytyk zapomniany?, [w:] S. Ropelewski, Pisma krytyczne, oprac. J. Lyszczyna, Katowice 2014, s. $20-21$.

66 Z. Szmydtowa, Stowacki-Cervantes..., s. 230. 
O Boże! ileż bym stworzył romansów,

Gdybym chciał wszystkich d...w być zabawą,

Wyspą dla grubych naszych Sanczo Pansów,

$\mathrm{Na}$ której by się uczyli ze sławą

Sylabizować. Lecz z prozą aliansów

Nie chcę - do wiersza mam, jak sądzę, prawo.

Sam się rym do mnie miłośnie nagina,

Oktawa pieści, kocha mię sestyna ${ }^{67}$.

Sekundantem Słowackiego został Ludwik Nabielak, który niczym Sancho Brzuchacz, postępował bardzo roztropnie, racjonalnie, ograniczając emocjonalne zachowania poety wynikające z niepohamowanego narcyzmu. Nasuwa się analogia niedoszłego pojedynku z Ropelewskim ze sceną zamierzonej walki bohatera powieści Cervantesa z lwami, które ostatecznie zlekceważyły swojego przeciwnika ${ }^{68}$. Ropelewski był wytrawnym żołnierzem, brał udział w powstaniu listopadowym, następnie wyemigrował do Paryża, a później wziął udział w zakończonej niepowodzeniem wyprawie Józefa Zaliwskiego w 1833 roku. Słowacki takiego żołnierskiego doświadczenia nie miał. Strzał oddany przez kogoś tak doświadczonego jak Ropelewski mógł mieć tylko jeden skutek. Motyw tchórzostwa należy całkowicie odrzucić. Krytyk zachował się zatem niczym lew z powieści Cervantesa, który darował don Kichotowi życie, ignorując go: „Ale lew wspaniałomyślny, bardziej dworny niż zuchwały, nie zważając na dzieciństwa i pyszałkowatość, obejrzawszy się na tę i na tamtą stronę, jak rzekliśmy, odwrócił się ukazawszy tył Don Kichotowi i z wielką flegmą, i spokojem znowu się w klatce ułożył"69. Rozważania w tej części tekstu warto zakończyć słowami Ryszarda Przybylskiego, który stwierdza:

Średniowiecze miało swoich błędnych rycerzy. W wieku XIX w hotelikach i pałacach, na uniwersytetach i w przytułkach, w wojsku egipskim i wśród kanadyjskich drwali, wszędzie, może tylko z wyjątkiem obu biegunów, można było spotkać „błędnych Polaków”70.

Swoistym kontrapunktem dla Zawiszy Czarnego jest niedokończony dramat Słowackiego Beniowski, w którym „krytycyzm wobec wad polskich nabiera szczególnej ekspresji w charakterystyce antyintelektualizmu szlacheckiego"71. Poeta uczynił bohaterem tekstu tę samą postać, której poświęcił poemat dygresyjny, a akcję utworu umieścił w trakcie trwania konfederacji barskiej (1768-1772), podczas której w wędrówce Beniowskiego towarzyszy mu diabeł Pamfilus. Dramat ten był

67 J. Słowacki, Beniowski. Poema ..., s. 99.

68 Na tę analogię zwróciła uwagę M. Barbaruk, Dtugi cień Don Kichota, Kraków 2015, s. 123.

69 M. de Cervantes Saavedra, Przemyślny szlachcic Don Kichot z Manczy, cz. II, przeł. A.L. Czerny, Z. Czerny, Warszawa 1957, s. 157.

70 R. Przybylski, Podróż Juliusza Stowackiego na Wschód, Kraków 1982, s. 12.

71 M. Piszczkowski, Wieś w twórczości Stowackiego, „Pamiętnik Literacki” 1964, z. 1, s. 123. 
już rozpatrywany w kontekście innych dramatów wieszcza, ponieważ Słowacki fragmenty dramatu o Beniowskim włączył do tekstu Samuela Zborowskiego ${ }^{72}$, ale do tej pory nikt nie dokonał jego egzegezy w kontekście Zawiszy Czarnego.

Należy dodać ważną informację o dacie powstania utworu - najprawdopodobniej poeta ukończył (zarzucił) pracę nad tekstem w pierwszej połowie 1842 roku $^{73}$, nie zaś, jak chcą autorzy Kalendarza życia i twórczości Juliusza Stowackiego, w roku $1838^{74}$. Dlaczego Słowacki nie mógł napisać Beniowskiego-dramatu wcześniej? Stanisław Makowski wśród argumentów wskazuje koncepcję postaci Beniowskiego i księdza Marka oraz wyklucza możliwość powstawania równocześnie dramatu i poematu ${ }^{75}$. Warto dodać jeszcze jedną hipotezę. Poeta nie mógł napisać fragmentu dramatycznego wcześniej z podobnego powodu, dla którego nie powinno się datować później Fantazego na rok 1844 lub 1845, tylko 1841, ponieważ w tym właśnie roku następuje załamanie dotychczasowej drogi twórczej (poemat Beniowski) i życiowej (niedoszły pojedynek z Ropelewskim) Słowackiego: „Fantazy jest więc drugim świadectwem kryzysu języka romantycznej poezji, bowiem o tym samym świadczy co Beniowski. Z czego wynika, że musiał być w tym samym czasie napisany. Czyli gdzieś w roku 1840 lub 1841" "76. Beniowski — dramat również jest świadectwem kryzysu języka romantycznego, tak jak Beniowski — poemat czy komedia Fantazy, nawet więcej, ponieważ ,została tu przekroczona granica destrukcji kultury romantycznej" "77.

Alina Kowalczykowa zwróciła uwagę, że w Beniowskim „legenda o śpiących rycerzach pozwala Słowackiemu ukazać Polaków na wzór bohaterów, czekających na przebudzenie" 78 , natomiast wędrówka głównego bohatera przypomina motyw dantejski ${ }^{79}$. Jest to, w pewnym sensie, motyw dantejski à rebours, zniekształcony, a zatem groteskowy, ponieważ to nie ktoś tak zasłużony i chwalebny jak Wergiliusz w poemacie Alighieriego towarzyszy Beniowskiemu, ale diabeł i szyderca Pamfilus, a wędrówka odbywa się po piekle, ale ziemskim. Magdalena Saganiak, analizując Poema Piasta Dantyszka, stwierdzała, że „odwrócenie polskiego mitu narodowego dokonuje się poprzez groteskowe odkształcenie sta-

72 Zob. T. Dąbrowski, ,, Samuel Zborowski” a „Beniowski”, „Pamiętnik Literacki” 1907, z. 1, s. $85-89$.

73 Zob. S. Makowski, Dramat o Beniowskim, [w:] idem, Tęcze i świerzopy. Słowacki, Beniowski, Mickiewicz, Wrocław 1984, s. 199.

74 Zob. Kalendarz życia i twórczości Juliusza Stowackiego..., s. 330.

75 S. Makowski, Dramat o Beniowskim..., s. 198-199.

76 J.M. Rymkiewicz, Juliusz Stowacki pyta o godzinę..., s. 51.

77 M. Saganiak, Człowiek i doświadczenie wewnętrzne. Późna twórczość Mickiewicza i Stowackiego, Warszawa 2009, s. 206.

78 A. Kowalczykowa, Stowacki, Warszawa 1994, s. 323. Drugą polską legendą, którą poeta poruszył w omawianym utworze, jest legenda o Wandzie, szerzej na ten temat zob. M. Ruszczyńska, Stowianie i słowianofile. O słowianofilskich dyskursach $w$ literaturze polskiego romantyzmu, Kraków 2015, s. 164-166. Szerzej na temat motywu śpiących rycerzach w literaturze zob. F. Ziejka, Z dziejów literackiej sławy śpiących rycerzy, „Pamiętnik Literacki” 1983, z. 2, s. 23-49.

79 Zob. A. Kowalczykowa, op. cit., s. 324. 
rożytnych i romantycznych toposów. W niebie nie może być nic groteskowego. Przeciwnie w piekle, tam wszystko jest mniej lub bardziej groteskowe" ${ }^{\text {" }}$. Te słowa zdają się również współgrać z estetyczną i historiozoficzną koncepcją Słowackiego w Beniowskim, fragmencie dramatycznym.

Scena I aktu I rozpoczyna się od momentu, gdy Beniowski ratuje Księżniczkę, pod którą postrzelono konia:

\section{BENIOWSKI}

(wraca, niosąc Księżniczkę.)

Precz mi z rumaka... patrzaj — draśnięta,

Koń jej zabity... koń biały jak śnieg...

Leżała pod nim jak róża zmięta... ${ }^{81}$

Jest olśniony jej pięknością, zanosi ją w bezpieczne miejsce, do chaty. Można przypuszczać, że w ten sposób nawiąże się wątek miłosny między wybawicielem — dzielnym rycerzem — a piękną Księżniczką, znany z romansów rycerskich i zgodny z ich poetyką. Słowacki jednak ucina motyw, kończy go, zanim jeszcze zdążył się rozwinąć. Pamfilusowi zależy bowiem, aby nie dopuścić do narodzin uczucia: „Miłość go może wydrzeć z moich ręku i powróci czystym władzom duszy... a to jest człowiek, który ma pokruszyć zęby na białym marmurze sławy..."82. Następuje celowe zdeformowanie wzorca rycerskich opowieści. Sława została przedstawiona jako pokusa piekła i przeciwstawiona miłości. W Zawiszy Czarnym tytułowy bohater porzuci miłość dla walki, dla wielkiego czynu, chociaż nie będzie pragnął zostać sławnym: „Nie dbam ja o pieśni... a nie dbam też o głupich namowy i o samolubów nauki... Ojczyz[na] — to nie jest między granicami... ale rościąga się aż tam, gdzie jej tchnienie dochodzi... gdzie jej sława panuje... gdzie jej duch przeważa..." (ZC, Ustępy zaniechane i przekreślony ustęp fragmentu I (po w. 81), s. 376).

Literacki duet Beniowskiego i Pamfilusa rozpatrywano w paraleli do Fausta i Mefistofelesa ${ }^{83}$. Warto zarysować zbieżność z innymi słynnymi towarzyszami: don Kichotem i Sancho Brzuchaczem. Pamfilus często w swoich wypowiedziach

80 M. Saganiak, Groteska u Stowackiego..., s. 208.

81 J. Słowacki, Beniowski. Dramat niedokończony, oprac. J. Kleiner, J. Kuźniar, [w:] idem, Dzieła wszystkie, red. J. Kleiner, t. X, Wrocław 1957, s. 16.

82 Ibidem.

83 Zob. M. Korzeniewicz, Ludowość ironiczna $w$ dramacie o Beniowskim, [w:] eadem, Od ludowości ironicznej do ludowości mistycznej. Przemiany postaw estetycznych Słowackiego, Wrocław 1981, s. 51-56 (tutaj także bogate wskazówki bibliograficzne w zakresie wspominanego aspektu zob. przypis nr 1, s. 51); S. Makowski, Dramat o Beniowskim ..., s. 199-200. Notabene w filmie Andrzeja Żuławskiego Diabeł pojawia się również wątek wędrówki wysłannika piekła z głównym bohaterem utworu Jakubem, wzorowanym na Kordianie, w ogarniętej porozbiorowym chaosem Polsce, zob. Diabet, reż. A. Żuławski, Polska, 1972. Szerzej na temat filmu i jego związków z romantyzmem zob. M. Olszewska-Jończyk, ,Witalność kina przebiega przez jego złe, a nie dobre gusta”. „Diabet” Andrzeja Żuławskiego, „Kwartalnik Filmowy” 2009, nr 66, s. 80-92. Wydaje się, że zestawienie dramatu o Beniowskim z Diabłem otworzyłoby ciekawy horyzont poznawczy oraz wniosłoby nowe elementy interpretacyjne zarówno dla tekstu Słowackiego, jak i filmu Żuławskie- 
posługuje się prozą, co już jest argumentem zbliżającym go do Sancho. Obecność poezji i prozy „to sygnał, że poeta będzie tu operował ostrymi przeciwstawieniami języka poetyckiego i prozaicznego" 84 . Diabeł krytycznie odnosi się do poezji romantycznej podejmującej tematykę narodową:

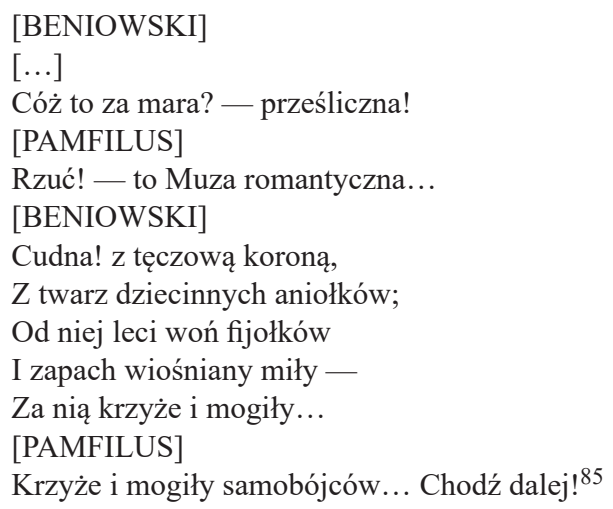

Beniowski charakteryzuje muzę uosabiającą poezję romantyczną, która jest cudna, pachnąca, ale za nią kryje się sfera śmierci, iście romantycznej: „krzyże i mogiły". Pamfilus dopowiada — samobójców, ponieważ romantycy stworzyli „sposób wysłuchiwania i dialogu z innością najbardziej drastyczną: ze śmiercią, wydając się na niewyrażalność po to, aby uniknąć uprzedmiotowienia śmierci"86. Bezpośrednie nawiązanie do postaci don Kichota pojawia się w słowach Pamfilusa, w akcie I, scenie IV, gdy w Skandynawii pokazuje Beniowskiemu scenę walki Odyna ze świętą Wandą: „Patrz raczej... tam pod drzewa... Widzisz jeden z najdziwaczniejszych pojedynków... Od czasu Don Kiszota nie było tak głupiej walki" ${ }^{87}$. Połączenie dwóch zupełnie odmiennych kulturowo komponentów mitologicznych - słowiańskich i skandynawskich - jest groteskowe, ponieważ groteska łączy z sobą sprzeczne elementy. Na uwagę zasługuje również stan Wandy:

Przypatrz się - to święta Wanda,

Co dziś - jak spita od chmielu

Powstała we śnie z Wawelu

I tu się — jak rybka rzuca... ${ }^{88}$

Gdy Beniowski zdecyduje się pomścić polską bohaterkę, usłyszy prześmiewcze, niezwiązane z powagą sytuacji słowa Pamfilusa:

go, a także poszerzyłoby obraz niezaprzeczalnej obecności romantyzmu w kulturze dwudziestowiecznej.

84 W. Weintraub, „Balladyna”, czyli zabawa w Szekspira, „Pamiętnik Literacki” 1970, z. 4, s. $86-87$.

85 J. Słowacki, Beniowski. Dramat niedokończony..., s. 27.

86 M. Janion, Niesamowita Słowiańszczyzna. Fantazmaty literatury, Kraków 2007, s. 70.

87 J. Słowacki, Beniowski. Dramat niedokończony..., s. 31.

88 Ibidem. 
[PAMFILUS]

Gdzie lecisz, szaleńcze?

[BENIOWSKI]

Zemszczę...

[PAMFILUS]

Czas rozwinąć tęczę... ${ }^{89}$

Tęcza symbolizuje nadzieję, zmiany i przemiany, następuje po burzy, zapowiada lepsze czasy, a w dramacie Słowackiego, z didaskaliów, czytelnik dowiaduje się, że „Wszystko znika. — Okolica nad jeziorem. — Mogiła"90.

Warto zwrócić uwagę na deprecjonujący epitet, który pojawił się w komentarzu Pamfilusa dotyczącym pojedynku Wandy z Odynem. Walka od czasu don Kichota jest „głupia”. Można przyjąć, że te słowa, w pewnym stopniu, reprezentują myśli i przekonania autora, co w przypadku Słowackiego nie byłoby w żadnym razie zaskakujące. Wiktor Weintraub w ten sposób tłumaczy genezę imienia Pamfilus w Beniowskim:

Znaczące jest już jego imię. Wywodzi się ono z greckiego „pamphilos” — ukochany przez wszystkich. Nadał więc Słowacki „na pośmiewisko sprzeczne z naturą nazwisko” diabłu. I gra ono aluzjami literackimi. Pod takim to imieniem, Panfilo, wprowadził Boccaccio do Dekameronu i do Fiammetty autorskiego sobowtóra. Czy można by wobec tego założyć, że Słowacki traktował owo imię jako aluzję literacką, że chciał poprzez nie zasugerować, iż nałożywszy maskę diabła, sam wszedł między postaci swego dramatu? ${ }^{91}$

Biorąc pod uwagę hipotezę Weintrauba, że za Pamfilusem przemawia sam Słowacki, wypada dojść do wniosku, że dramaturg nie cenił zbyt wysoko przygód don Kichota, a przede wszystkim pojedynków najsłynniejszego błędnego rycerza, skoro określił je mianem głupich. Jak w takim razie owa hipoteza koreluje z cytowanym na początku artykułu listem do matki, w którym poeta zapewniał: „nic równego jak Donkihote”? Ze znaczenia i doniosłości Don Kichota w dziejach literatury Słowacki doskonale zdawał sobie sprawę, a zatem musiał również dostrzegać groteskowy i prześmiewczy charakter powieści. „Głupią” walkę należałoby interpretować nie tyle jako bezcelową, ale na pewno bezsensowną, podejmowaną na próżno w iście syzyfowym wysiłku, bez możliwości zwycięstwa. Czy takiej walki nie podejmuje Zawisza Czarny pod koniec dramatu? Czy w ten sposób nie walczył don Kichot? Wbrew przeciwnościom losu (don Kichot) i wbrew przeciwnościom historii (Zawisza) wszakże ,nie ma takiego losu, którego nie przezwycięży pogarda" 92 . Za tą walką prowadzoną w zakończeniu pierwszego tomu powieści Cervantesa kryje się śmierć, chociaż narrator zaznacza, że w przypadku don Kichota ,ani o jego końcu i dopełnieniu żywota nie potrafił nic

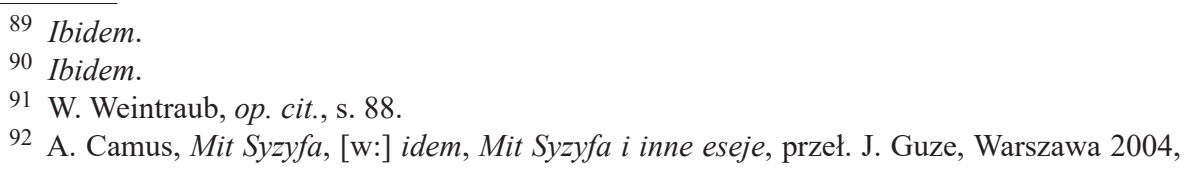
s. 167. 
znaleźć"93, dopóki nie natrafił na epitafium, z którego czytelnik dowiaduje się jedynie, iż „Ten, co na błędnym Chabettonie jeździł,/ Spoczywa tu, pod zimnym kamieniem"94. Opis śmierci jest odbiorcy darowany. Podobnie uczynił Słowacki — nie dopowiedział końca, chociaż go wyraźnie zasugerował ${ }^{95}$.

W świetle powyższych analiz i interpretacji zasadne wydaje się postawienie tezy o możliwej, a wręcz wysoce prawdopodobnej, inspiracji Słowackiego Don Kichotem Cervantesa przy pisaniu dramatu Zawisza Czarny oraz wcześniejszego fragmentu dramatycznego Beniowski. Hiszpańska powieść będąca kpiną z romansów i eposów rycerskich, być może, stała się dla autora Kordiana punktem odniesienia przy kreowaniu świata przedstawionego omawianych utworów. Egzemplifikacją tych twierdzeń jest Zawisza Czarny, którego tytułowy bohater jawi się jako błędny rycerz owładnięty szaleństwem i nieszczęśliwą miłością, podobnie jak bohater Don Kichota. Reinterpretacja w warunkach kultury polskiej, której dokonał autor Samuela Zborowskiego, opiera się na postępującej demitologizacji Sulimczyka, dzięki zastosowaniu ujęć groteskowych, ukazywaniu go jako bohatera romantycznego owładniętego szaleństwem, wbrew wymogom i normom narodowej legendy konsolidującej polską wspólnotę emocjonalną.

\title{
Knights-errant by Juliusz Słowacki - Zawisza the Black and Beniowski
}

\author{
Summary
}

„Zawisza the Black” and „Beniowski” (drama) there are one of poorly discussed works by Juliusz Słowacki. The unfinished dramas by the poet, dating from the late, mystical phase of his literature, opens a wide field of research. It appears advisable to place the thesis of a possible inspiration Słowacki „Don Quixote” by Miguel de Cervantes Saavedra when writing drama „Zawisza the Black” and „Beniowski” (drama). Spanish novel, which is a mockery of chivalric romances and epics, perhaps, has become for author of „Kordian” point of reference for the creation of the world presented these works. Exemplification of these claims is to analyse „Zawisza the Black”, whose title character is seen as knight-errant possessed by madness and unhappy love, like the character of „Don Quixote”. Reinterpretation of the conditions of polish culture made by Słowacki based on demythologization the most famous knight.

93 M. de Cervantes Saavedra, Przemyślny szlachcic..., s. 636.

94 Ibidem, s. 637.

$95 \mathrm{~W}$ podobny sposób, ponad 150 lat później, zakończy swoją relację podmiot liryczny w wierszu Wisławy Szymborskiej poświęconym fotografii ludzi wyskakujących z okien budynków World Trade Center podczas tragedii, która wydarzyła się 11 września 2001 roku: „Tylko dwie rzeczy mogę dla nich zrobić —/ opisać ten lot/ i nie dodawać ostatniego zdania”. W. Szymborska, Fotografia z 11 września, [w:] eadem, Chwila, Kraków 2002, s. 35. 